\title{
シクロデキストリンとその誘導体による水分収着挙動
}

緒方文彦, ${ }^{a}$ 早㴊凌平, ${ }^{a}$ Chalermpong Saenjum,,$b$ 中村武浩, ${ }^{a}$ 川崎直人 ${ }^{*, a, d}$

\section{Adsorption Behavior of Water on Virgin and Modified Cyclodextrin}

\author{
Fumihiko Ogata, ${ }^{a}$ Ryouhei Hayabuchi, ${ }^{a}$ Chalermpong Saenjum, $, b, c$ \\ Takehiro Nakamura, ${ }^{a}$ and Naohito Kawasaki ${ }^{*, a, d}$ \\ ${ }^{a}$ Laboratory of Public Health, Faculty of Pharmacy, Kindai University; 3-4-1 Kowakae, Higashi-Osaka, Osaka 577-8502, \\ Japan.: ${ }^{b}$ Faculty of Pharmacy, Chiang Mai University; Suthep Road, Muang District, Chiang Mai, 50200, Thailand: \\ ${ }^{c}$ Cluster of Excellence on Biodiversity-based Economics and Society (B.BES-CMU), Chiang Mai University; \\ Suthep Road, Muang District, Chiang Mai, 50200, Thailand: and ${ }^{d}$ Antiaging Center, Kindai \\ University; 3-4-1 Kowakae, Higashi-Osaka, Osaka 577-8502, Japan.
}

(Received April 12, 2020; Accepted May 29, 2020)

Relationship between water molecules and parent and hydroxypropylated cyclodextrins (denoted as CD and HP$\mathrm{CD}$ ) was assessed in this paper. The trends in ad-desorption isotherms of $\mathrm{CD}$ for water molecule were quite different compared to those of HP-CD. Ad-desorption isotherms of CD showed the hysteresis under our experimental conditions. The molar ratio of hydration (R-value) using $\alpha-\mathrm{CD}, \beta-\mathrm{CD}, \gamma-\mathrm{CD}$, HP- $\alpha-\mathrm{CD}, \mathrm{HP}-\beta-\mathrm{CD}$, and HP- $\gamma$-CD was 7.1, 11.4 , $13.5,12.5,14.0$, and 16.7 , respectively. These results indicated that the adsorption capability of water molecule of HP$\mathrm{CD}$ was greater than that of $\mathrm{CD}$. Additionally, the changes in characteristics of $\mathrm{CD}$ and HP-CD at different water activity conditions were demonstrated. X-ray diffraction patterns were significantly different between CD and HP-CD. The crystal structure of HP- $\alpha-C D, H P-\beta-C D$, and HP- $\gamma$-CD showed amorphous at different water activity conditions. Finally, sorption entropy and heat of sorption of water molecules were calculated in this experiment. In summary, these results provide useful information for understanding the relationship between water molecules and parent and hydroxypropylated cyclodextrins.

Key words——water molecule; cyclodextrin; hydroxypropyl-cyclodextrin; adsorption

\begin{abstract}
緒 $\overline{\overline{\bar{一}}}$

シクロデキストリン（cyclodextrin;CD）とは， グルコース残基が $\alpha-1,4$ 結合した環状のオリゴ糖で あり，構造は底の抜けたバケツに例えられることが 多い. $\mathrm{CD}$ の環状構造は，その外側を $\mathrm{OH}$ 基に由来 する親水性領域，その内側を $\mathrm{CH}$ 基に由来する疎 水性領域から構成されている. CD の特徵の 1 つに 「包接作用」があり，その構造中の空洞内に有機化 合物などを取り込むことができる。 ${ }^{1,2)} こ の \mathrm{CD}$ の包 接作用を論じる上で重要な因子の 1 つに水分子の存 在（水分子との相互作用）が挙げられる. CD を食
\end{abstract}

${ }^{a}$ 近畿大学薬学部公衆衛生学研究室, ${ }^{b}$ Faculty of Pharmacy, Chiang Mai University, ${ }^{c}$ Cluster of Excellence on Biodiversity-based Economics and Society (B.BESCMU), Chiang Mai University, d近畿大学アンチエイ ジングセンター

*e-mail:kawasaki@phar.kindai.ac.jp
品香料に応用した先行研究によると, CD の周囲に ゲスト分子としてフレーバー及び水分子が存在した 場合，水分活性（水分子の存在）に依存し，ホスト 分子の包接能が変化したことが報告されている. ${ }^{1,3)}$ すなわち，水分子の存在下において CD と水分子が 相互作用を起こし, CD の物理化学的特徵が変化し

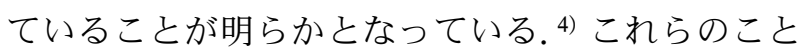
から，CD の包接作用を評価する場合， $\mathrm{CD}$ と水分 子との相互作用を明らかとすることは重要であるこ とがわかる。これまでに CD の包接作用を活かした 使用用途としては，食品，化粧品，医薬品及び環境 分野など多岐にわたつている. ${ }^{4)} \mathrm{CD}$ と水分子との 相互作用においては，1980 年代から基礎研究が実 施されているが，そのほとんどが未修飾の $\alpha-C D$, $\beta-\mathrm{CD}$ 及び $\gamma-\mathrm{CD}$ に限定されている. ${ }^{5-7)}$

近年，機能性の向上を企図して多種多様な CD の 誘導体が開発・研究されている. ${ }^{8)}$ 具体的な $\mathrm{CD}$ 誘 導体としては，（ランダム）メチル基 [randomly 
methylated (RM)- $\beta$-CD]，ヒドロキシプロピル基 [hydroxylpropylated (HP) $-\beta$-CD 及び HP- $\gamma$-CD] 及びスルホブチルエーテル基 [ sulfobutylether (SBE) - $\beta$-CD］などで修飾されたものが挙げられ る。その中で，実用化に向けて盛んに研究されてい るものの 1 つがヒドロキシプロピル基で修飾された CD (HP-CD) である. ${ }^{8)}$ 家庭用品及び化粧品分野 においては応用研究が進んでおり，消臭マスキング 効果や効能持続効果を目的に HP- $\beta-C D$ が使用され ている. ${ }^{6}$ 医薬品分野においては，医薬品の水への 溶解度改善及び安定性向上を目指し，HP- $\beta$-CD が 医薬品添加剂として使用されている. ${ }^{1,9)}$ さらに近年 では，HP- $\beta-C D$ の投与がニーマン・ピック病 C 1 型の病状進行を遅らせる可能性があると報告されて いる. ${ }^{10)}$ またアメリカ食品医薬品局は，2018 年に成 人における巣状分節性系球体硬化症に対する治療薬 として HP- $\beta$-CD の開発を許可している. ${ }^{11,12)}$ これ らのことから，HP-CD の誘導体は幅広い分野で有 効的に使用されているのが現状である.

しかしながら，この HP- $\beta$-CD はアメリカ薬局方 及びヨーロッパ薬局方には収載されているものの, 2019 年現在のところ日本薬局方には収載されてい ない。また，HP-CD が CD と同様に幅広い分野で 有効的に使用されるためには，より詳細な諸物性評 価などが必要であると考えられ，先述したように私 たちの身の回りにかならず存在し, CD の物理化学 的特徴に影響を与える水分子との相互作用を評価す ることは非常に重要であると考えられる，さらに， 水分活性の影響を考慮した CD 及び HP-CD と水分 子との相互作用に関する研究は，ほとんど報告され ていないのが現状である，以上のことを背景に本論 文では，CD 及び HP-CD を用い水分子との相互作 用に関する基礎的検討を実施した。

\section{方法}

1. 試料 $\alpha$-シクロデキストリン $(\alpha-\mathrm{CD}, \mathrm{CAS}$ Number 10016-20-3, Mw 972.84)， $\beta$-シクロデキス トリン ( $\beta$-CD, CAS Number 7585-39-9, Mw 1134.98), $\gamma$-シクロデキストリン（ $\gamma$-CD， CAS Number 17465-86-0, Mw 1297.12)，及びヒドロキシプロピル 基で修飾されたヒドロキシプロピル- $\alpha$-シクロデキ ストリン (HP- $\alpha$-CD, CAS Number 128446-33-3,

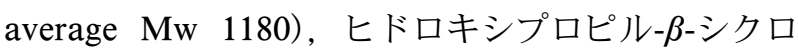

デキストリン (HP- $\beta$-CD, CAS Number 128446-35-5, average $\mathrm{Mw}$ 1380), ヒドロキシプロピル- $\gamma$-シクロ デキストリン (HP- $\gamma$-CD, CAS Number 128446-34-4, average Mw 1580) を試料とした（Sigma-Aldrich Japan，東京）。なお，本実験で使用した HP- $\alpha$ - CD， HP- $\beta$-CD 及び HP- $\gamma$-CD の平均置換度はそれぞれ $3.5,4.2$ 及び 4.8 である。各試料は， $110^{\circ} \mathrm{C}$ で 3 時 間真空乾燥後，実験に供した。各試料の構造式を Fig. 1 に示す.

2. 水分収着等温線 塩類飽和溶液法 ${ }^{13)}$ により 各種水分活性（water activity; Aw）に調製された 秤量瓶に各種 $\mathrm{CD}$ を $0.3 \mathrm{~g}$ 添加した。収着量及び脱 着量は, $30^{\circ} \mathrm{C}$ における 24 時間静置前後の重量差か ら算出した。 Table 1 に塩類飽和溶液により調製さ れる Aw を示す。

3. CD の諸物性評価各種 $\mathrm{CD}$ の諸物性評価 は，以下の方法により実施した。なお測定時におけ る Aw は， $0.00,0.11,0.51$ 及び 0.83 とした。電子 顕微鏡写真は, 低真空型電子顕微鏡装置 SU1510 （株式会社日立製作所，東京）にて撮影した。粉末 $\mathrm{X}$ 線回折分析は, 卓上型粉末 $\mathrm{X}$ 線回折装置 MiniFlex II（株式会社リガク，東京）にて測定し た. 熱重量・示差走查熱分析（thermal gravimetricdifferential thermal analyzer; TG-DTA) は, 熱重 量・示差走査熱分析装置 TG8120（株式会社リガ ク，東京）により測定し，昇温温度 $10^{\circ} \mathrm{C} / \mathrm{min}$ の条 件下， $500^{\circ} \mathrm{C}$ まで昇温した。

4. 水分収着によるエントロピー及び収着熱の変 化 水分収着のエントロピー変化 $\left(\Delta S_{e q}\right)$ は水分 収着等温線のデー夕を基に以下の Eq. (1) 及び Eq. (2) から平衡収着熱 $\left(Q_{e q}\right)$ を算出し, $Q_{e q}$ を Hill の 式 Eq. (3)に代入することにより求めた. さらに, Clausius-Clapeyron の式 Eq. (4)より，微分収着熱 $\left(q_{s t}\right)$ を算出した. ${ }^{14)}$

$$
\begin{gathered}
Q_{e q}=-\mathrm{R}\left\{d\left(\ln A_{W}\right) / d(1 / \mathrm{T})\right\}_{\phi} \\
\phi=\mathrm{RT} \int M d\left(\ln A_{W}\right) \\
\Delta S_{e q}=-Q_{e q} / \mathrm{T}-\mathrm{R} \ln \left(a_{W}\right) \\
q_{s t}=-\mathrm{R}\left\{d\left(\ln A_{W}\right) / d(1 / \mathrm{T})\right\}_{\mathrm{M}}
\end{gathered}
$$

ここで，申は表面エネルギー $(\mathrm{J}) ， \mathrm{R}$ は気体定数 $(\mathrm{J} / \mathrm{mol} \cdot \mathrm{K}), A_{W}$ は水分活性， $\mathrm{T}$ は絶対温度 $(\mathrm{K})$, $\mathrm{M}$ は水分含量 $(\mathrm{mg} / \mathrm{g}), a w$ は $30^{\circ} \mathrm{C}$ の同一水分含量 に対する水分活性の平均值である. 


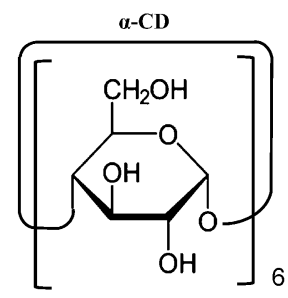

HP-a-CD

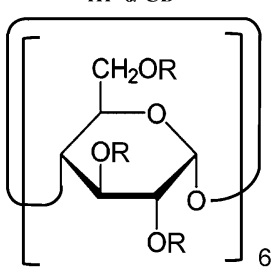

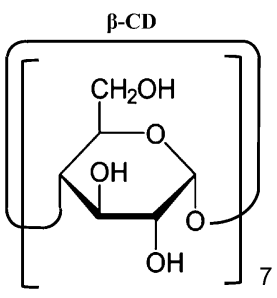

HP- $\beta-C D$

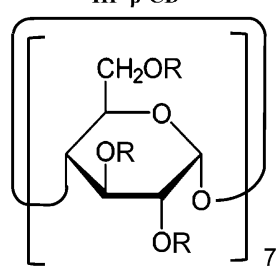

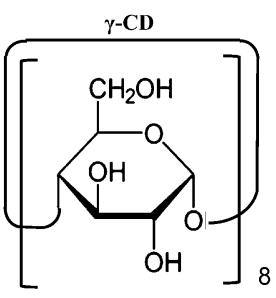

HP- - -CD

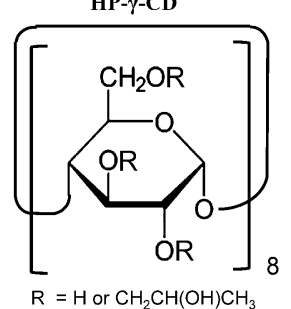

Fig. 1. Chemical Structures of Parent and Hydroxypropylated Cyclodextrins

Table 1. Water Activities Prepared by Saturated Salt Solutions

\begin{tabular}{ccccccccccc}
\hline \hline Samples & After drying & $\mathrm{KOH}$ & $\mathrm{LiCl}$ & $\mathrm{MgCl}_{2}$ & $\mathrm{~K}_{2} \mathrm{CO}_{3}$ & $\mathrm{Mg}\left(\mathrm{NO}_{3}\right)_{2}$ & $\mathrm{NaCl}$ & $\mathrm{KCl}^{2}$ & $\mathrm{KNO}_{3}$ & $\mathrm{~K}_{2} \mathrm{SO}_{4}$ \\
\hline $\mathrm{Aw}$ & 0.00 & 0.07 & 0.11 & 0.32 & 0.43 & 0.51 & 0.75 & 0.83 & 0.92 & 0.97 \\
\hline
\end{tabular}

\section{結果及び考察}

1. 各種 CDによる収着・脱着等温線各種 $\mathrm{CD}$ を用いた場合の $30^{\circ} \mathrm{C}$ における水分の収着・脱 着等温線の結果を Fig. 2 に示す。 $\alpha-\mathrm{CD}$ を用いた場 合， $\mathrm{Aw}$ 約 $0.40 \%$ 以上で収着等温線と脱着等温線に 顕著な変化は認められなかった。 $\beta$-CD の収着・脱 着等温線の挙動は， $\alpha$-CD のそれと類似していた. さらに $\alpha-\mathrm{CD}$ を用いた場合と比較して， Aw 約 $0.40 \%$ 以下の領域での $\beta-\mathrm{CD}$ は，より多くの水分子 を保持できることが明らかとなった。 また， $\alpha-C D$ 及び $\beta$-CD において, 脱着等温線は収着等温線から 乘離した挙動を示すヒステリシスを示すことが分 かった。一方， $\gamma$-CD を用いた場合, Aw 約 0.150.70 の領域においてヒステリシスが確認できた.

ヒドロキシプロピル基で修飾された HP- $\alpha-\mathrm{CD}$, $\mathrm{HP}-\beta-\mathrm{CD}$ 及び HP- $\gamma-\mathrm{CD}$ を用いた場合，わずかな 乘離が認められるものの収着等温線及び脱着等温線 は類似した挙動を示すことが明らかとなった。CD による水分子の収着は，CD の内部まで浸透する 「吸収」と CD の外部で結合する「吸着」の 2 つの 因子から成り立つ（収着＝吸収＋吸着）。例えば, $\alpha-\mathrm{CD}$ 及び $\beta$-CD を用いた場合, $\mathrm{Aw}$ 約 0.40 付近ま では収着等温線と脱着等温線に乘離が認められてい
ることから，水分子が $\mathrm{CD}$ の内部に吸収され， $\mathrm{CD}$ と水分子が比較的強い結合状態であると考えられ る. すなわち，水分子は $\mathrm{CD}$ 内で結晶水となり脱着 できなかったと考えられる， $\beta$-CD においては Aw 約 0.40 以上の領域においても収着等温線と脱着等 温線に乘離が認められていることから，CD が水和 状態であることが示唆されている。一方， $\gamma$-CD に おいては，Aw 約 0.15 までの低湿度領域で乘離反 応が認められなかったことから， $\alpha-\mathrm{CD}$ 及び $\beta-\mathrm{CD}$ とは異なり，初期段階で吸着過程が優位に進行した 後に吸収過程が進及水和したものと考えられる，先 述したように，CD は底の抜けたバケツに例えられ ることが多い，その構造は，グルコースの 1 級水酸 基で構成されるやや狭い開口部と 2 級水酸基で構成 されるやや広い開口部が存在しており，構成されて いるグルコース数の増加に伴い，その内容積及び空 洞径は増大する [内容積 $\left(174-427 \AA^{3}\right)$ 及び空洞径 $(0.45-0.85 \mathrm{~nm}): \alpha-\mathrm{CD}<\beta-\mathrm{CD}<\gamma-\mathrm{CD}]$. また, $\mathrm{CD}$ の空洞内部に補足できる分子サイズも内容積及 び空洞径に依存して大きくなることが報告されてい る. ${ }^{15,16)}$ したがって，低 Aw 条件下においては， $\alpha$ $\mathrm{CD}$ 及び $\beta-\mathrm{CD}$ を用いた場合と比較し，水分子が $\gamma$ $\mathrm{CD}$ の空洞内で補足されることが難しく, $\gamma$-CD の 外部で結合する吸着が優位に進行したと考えられる. 

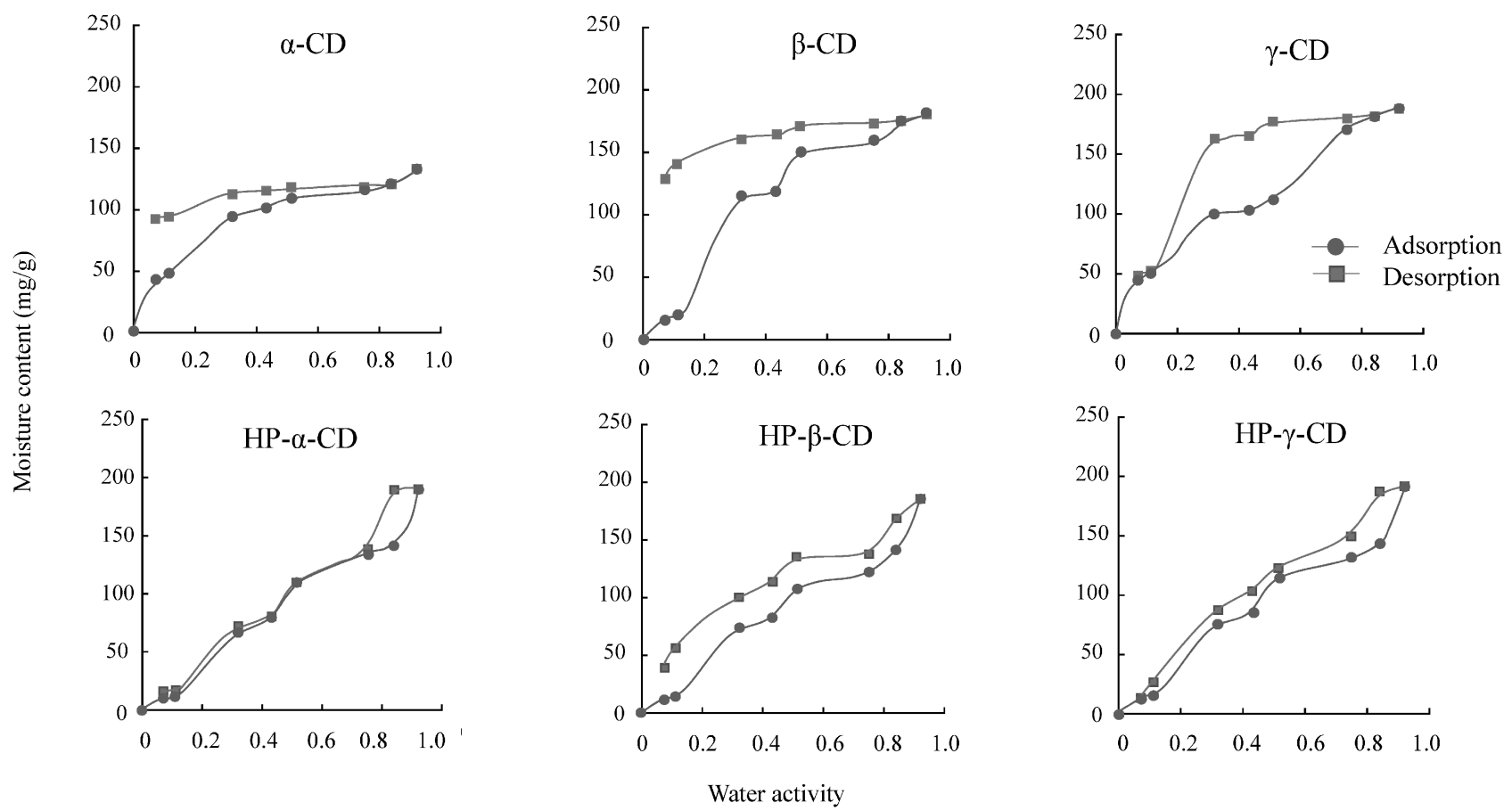

Fig. 2. Ad-desorption Isotherms of Water onto Different Type CDs

一方, HP- $\alpha-C D, H P-\beta-C D$ 及び HP- $\gamma-C D$ にお いては，全相対湿度領域において顕著な乘離反応が 認められなかったことから，CD 表面にける自由水 が関与する吸着過程が主に収着に寄与している可能 性が示唆された。

先行研究より, $\mathrm{CD}$ と水分子のモル数の関係（R 值）を評価する方法が報告されている. ${ }^{7,17)} \mathrm{R}$ 值は, 水分子のモル数を $\mathrm{CD}$ のモル数で除したものであ る.この $\mathrm{R}$ 值を用いることにより， 1 分子の $\mathrm{CD}$ に 対して水分子が何モル収着しているかを評価するこ とが可能である．水和状態で安定する最大の水分子 数（最大収着数）は, $\alpha-\mathrm{CD}$ で 6 分子, $\beta$-CD で 12 分子, $\gamma$-CD では 16 若しくは 17 分子と報告されて いる. ${ }^{7,17)}$ 本研究結果においては, $\alpha-\mathrm{CD}, \beta-\mathrm{CD}$ 及 び $\gamma$-CD を用いた場合の $\mathrm{R}$ 值は，それぞれ 7.1 分子， 11.4 分子及び 13.5 分子と類似した傾向を示した (Table 2). 先行研究より各種 CD $の \mathrm{H}$-donor $(\alpha-$ $\mathrm{CD}=18, \beta-\mathrm{CD}=21$ 及び $\gamma-\mathrm{CD}=24)$ 及び $\mathrm{H}-\mathrm{ac}-$ ceptor $(\alpha-\mathrm{CD}=30, \beta-\mathrm{CD}=35$ 及び $\gamma-\mathrm{CD}=40)$ の 值が明らかとなっている. ${ }^{18)}$ そこで，本研究で得ら れた $\mathrm{R}$ 值との相関係数 $\left(\mathrm{r}^{2}\right)$ を評価した. その結果,

H-donor 及び H-acceptor ともに 0.962 の正の相関 関係が認められた。これらのことから，各種 CD が 保持している H-donor 及び H-acceptor が水分子と
Table 2. The Molar Ratios of Hydration of Different Type CDs

Samples $\alpha$-CD $\beta$-CD $\gamma$-CD HP- $\alpha$-CD HP- $\beta$-CD HP- $\gamma$-CD

Molar

$\begin{array}{lllllll}\text { ratio of } & 7.1 & 11.4 & 13.5 & 12.5 & 14.0 & 16.7\end{array}$ hydration

の相互作用に関与していることが示唆された。な お，相互作用の様式に関しては，3.にて述べる.

HP- $\alpha-C D ， H P-\beta-C D$ 及び HP- $\gamma-C D$ を用いた場 合の $\mathrm{R}$ 值は，それぞれ 12.5 分子，14.0 分子及び 16.7 分子となり, 収着能が顕著に増大しているこ とが明らかとなった（Table 2)。CD の内容積は $\alpha$ $\mathrm{CD}<\beta$ - $\mathrm{CD}<\gamma$ - $\mathrm{CD}$ の順であり，各種 $\mathrm{R}$ 值と一致 した。これらの結果より，CD をヒドロキシプロピ ル基で修飾することにより，従来の水酸基の場合と 比較し，水分子との親和性が向上し，収着能が顕著 に改善されることを明らかとすることができた。さ らに，後述するように HP-CD は非晶質であるた め, 水分子との可逆的な反応が可能になったと考え られる。この現象は $\beta$-CD 及び $\gamma-\mathrm{CD}$ を用いた場合 と比較し， $\alpha$-CD を用いた水分子の収着・脱着等温 線で顕著に観察でき， $\mathrm{R}$ 值も最も高い 5.4 分子増加 することが分かった. 
Aw $\alpha-\mathrm{CD}$

0.00

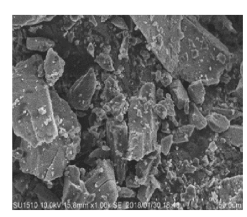

0.11

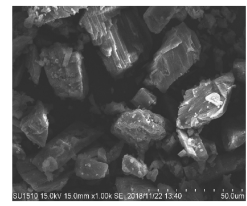

0.51

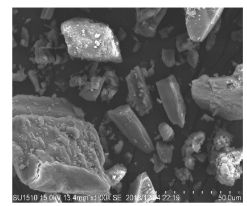

0.83

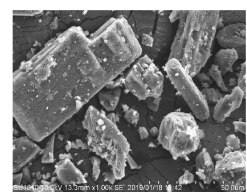

$\beta-C D$
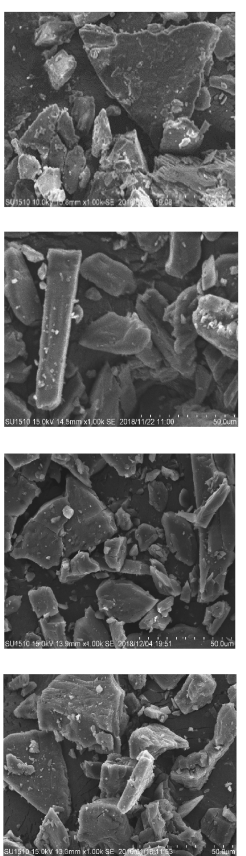

$\gamma-\mathrm{CD}$
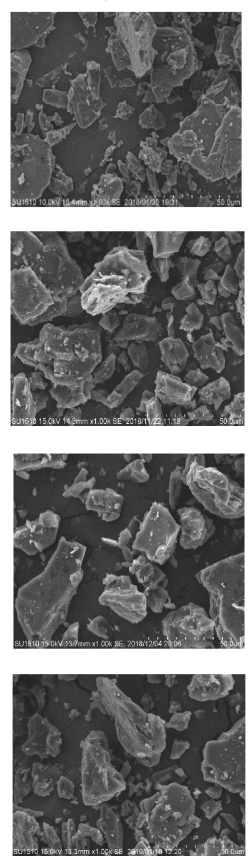

$\mathrm{HP}-\alpha-\mathrm{CD}$
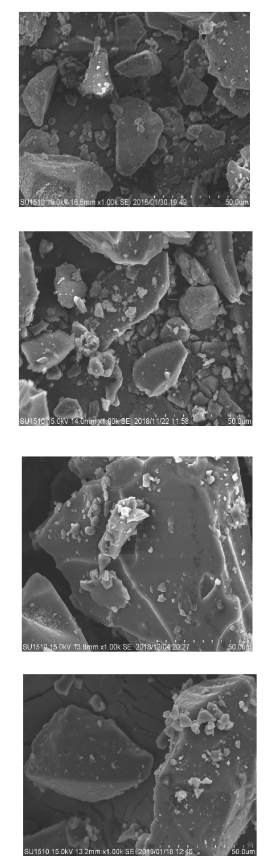

HP- $\beta-C D$
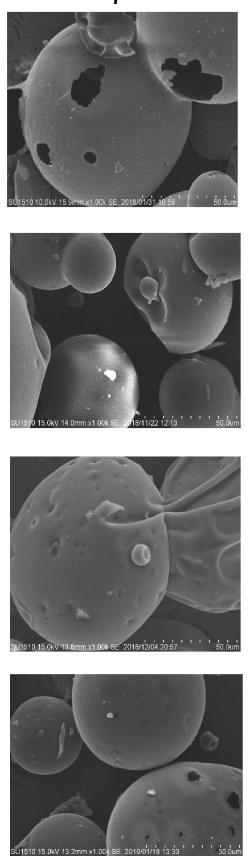

$\mathrm{HP}-\gamma-\mathrm{CD}$
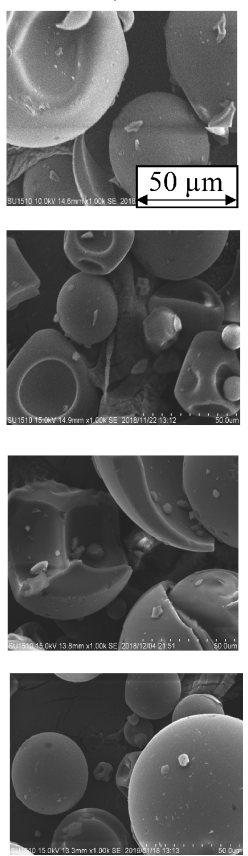

Fig. 3. SEM Images of Different Type CDs at Different Water Activity Conditions

2. 収着時における CD の諸物性変化 $\mathrm{Aw}$ 0.00 は理論上 $\mathrm{CD}$ と水分子とが相互作用していな い条件であり， $\mathrm{CD}$ 元来の諸物性を評価することが 可能である. また, 先行研究より Aw 0.31 以下で は水分子と $\gamma-\mathrm{CD}, \mathrm{Aw} 0.48$ では水分子と $\beta-\mathrm{CD}$, Aw 0.79 では水分子と $\alpha-C D$ が相互作用することが 報告されている.5)したがって，本実験における各 種 CD の諸物性評価は，Aw 0.00，0.11，0.51 及び 0.83 の条件時に実施した。 Aw $0.00,0.11,0.51$ 及び 0.83 における各種 CD の電子顕微鏡写真を Fig. 3 に示す。その結果，すべての $\mathrm{Aw}$ 条件下において $\alpha-\mathrm{CD}, \beta-\mathrm{CD}, \gamma-\mathrm{CD}$ 及び $\mathrm{HP}-\alpha-\mathrm{CD}$ の外観に顕著 な変化は認められず, 球形ではないことが明らかと なった。また，HP- $\beta$-CD 及び HP- $\gamma$-CD において は，粒形が球状であることが分かった。次に XRD の結果について Fig. 4 に示す. Aw 0.00 条件下にお ける $\alpha-\mathrm{CD}, \quad \beta-\mathrm{CD}$ 及び $\gamma-\mathrm{CD}$ の結晶構造の特徵 は, 先行研究3) 及び The powder diffraction file 2010 (The International Center for Diffraction Data) のそ れらと一致した。 $\alpha-\mathrm{CD}$ においては，Aw 0.00 のと きに $13.0,13.7$ 及び $14.7^{\circ}$ に特徵的なピークが観察 されたが，Awの増大に従ってそのピーク位置は, 低角度側へとシフトした。これらは，結晶構造が無 水状態から水和状態へ変化したものと考えられる.
$\beta$-CD に関しては，Aw 0.00 のときに 13.0 及び $13.5^{\circ}$ に特徵的なピークが観察された。また，Aw 0.48 のときに結晶構造が変化することが報告され ており,5) 本研究においても Aw 0.51 のときに同様 の変化が観察された。さらに， $\gamma$-CDにおいては,

Aw 0.00 のときに $12.6,16.9$ 及び $18.7^{\circ}$ に特徵的な ピークが観察され， $\beta$-CD と同様に Aw 0.51 で結晶 形に変化が認められた。これらの変化も先と同様に 結晶構造が無水状態から水和状態へ変化したものと 考えられる. 先行研究より, $\gamma-\mathrm{CD}$ は無水状態及び 水和状態の間の状態である，いわゆる中間状態の結 晶構造をとることができると報告されている. ${ }^{5)}$ そ のため, 本研究条件下においても，Aw 0.11 の結晶 形は Aw 0.00 及び Aw 0.51 の結晶形とは異なるこ とが明らかとなった。

先行研究より, $\alpha$-CD の空洞内及び空洞外には, 水分子がそれぞれ 2 分子及び 4 分子存在しているこ と, さらに， $\beta-\mathrm{CD}$ の空洞内及び空洞外には，水分 子がそれぞれ 7-8 分子及び 4-5 分子存在しているこ とが報告されている. ${ }^{17,19)}$ また， $\gamma$-CD に関しては 先述したように中間状態が存在することから， $\gamma$ $\mathrm{CD}$ の空洞内に水分子が 7-12 分子存在していると 考えられている.

一方, HP- $\alpha-\mathrm{CD}, \mathrm{HP}-\beta-\mathrm{CD}$ 及び HP- $\gamma-\mathrm{CD}$ の結 

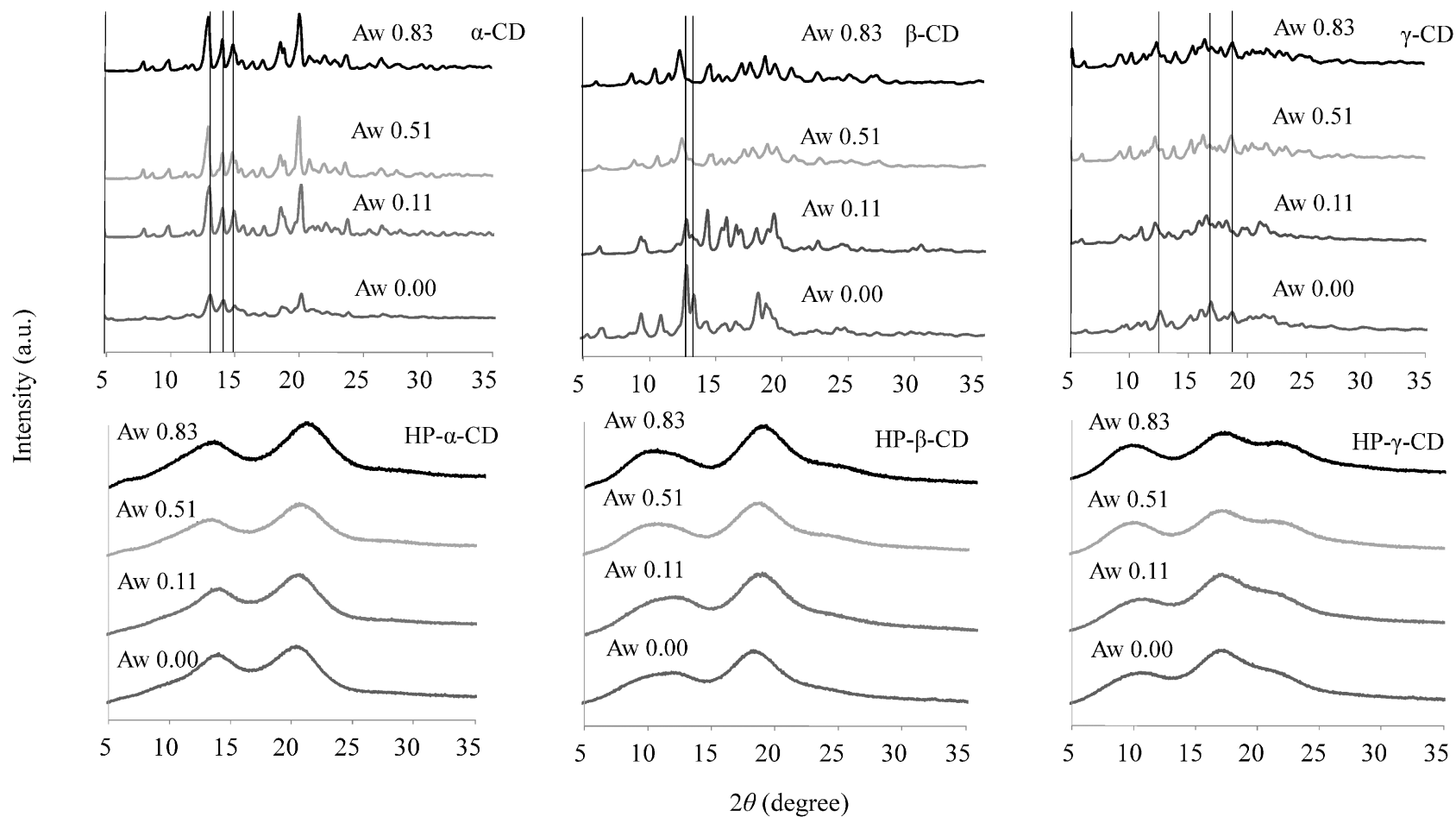

Fig. 4. XRD Patterns of Different Type CDs
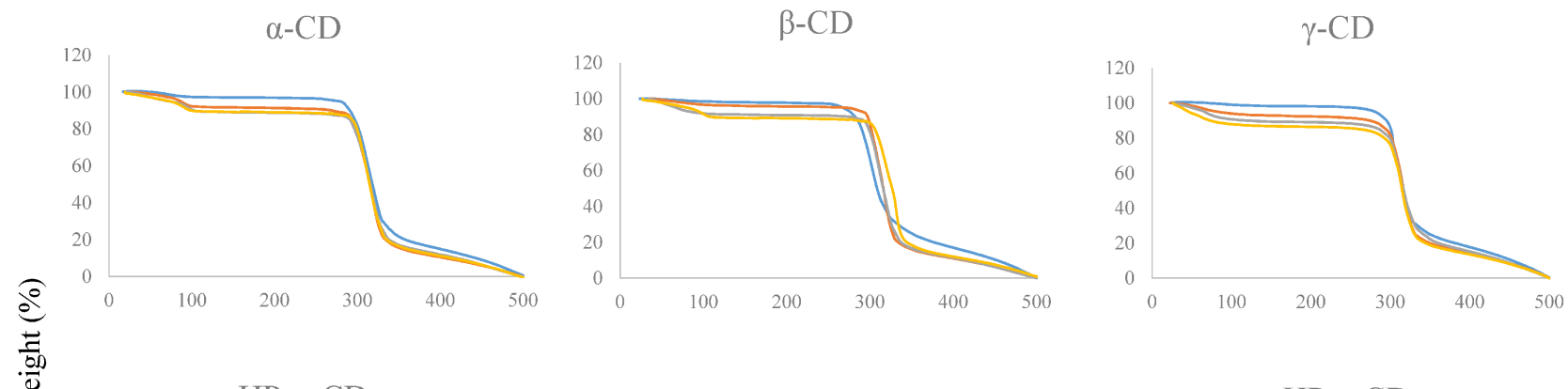

HP- $\alpha-C D$

HP- $\beta-C D$
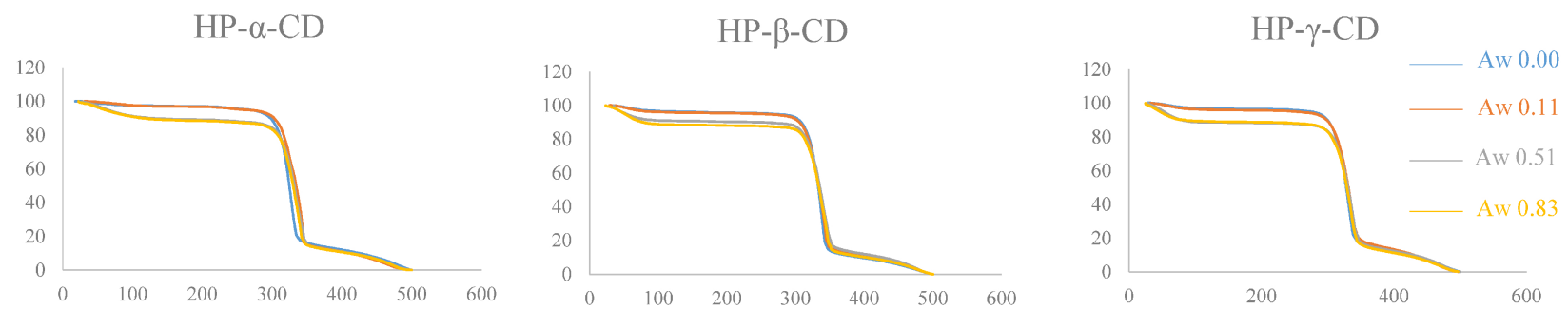

Temperature $\left({ }^{\circ} \mathrm{C}\right)$

Fig. 5. TG Curves of Different Type CDs

(Color figure can be accessed in the online version.)

晶構造においては，Aw 0.00 のときに非晶質である ことを確認し, Aw に依存してその結晶形は変化し ないことが分かった。また，先の HP-CD による水 分子の収着・脱着等温線（Fig. 2) 及び XRDの結 果（Fig. 4）より，水分子とHP-CD の相互作用に
は吸着過程（可逆的な反応）が主として関与してい ることから，水分子が HP-CD の結晶形に与える影 響が小さいと考えられる。

3. 収着時における CD の熱物性変化 各種 CD の熱重量分析の結果を Fig. 5 に示す. その結 


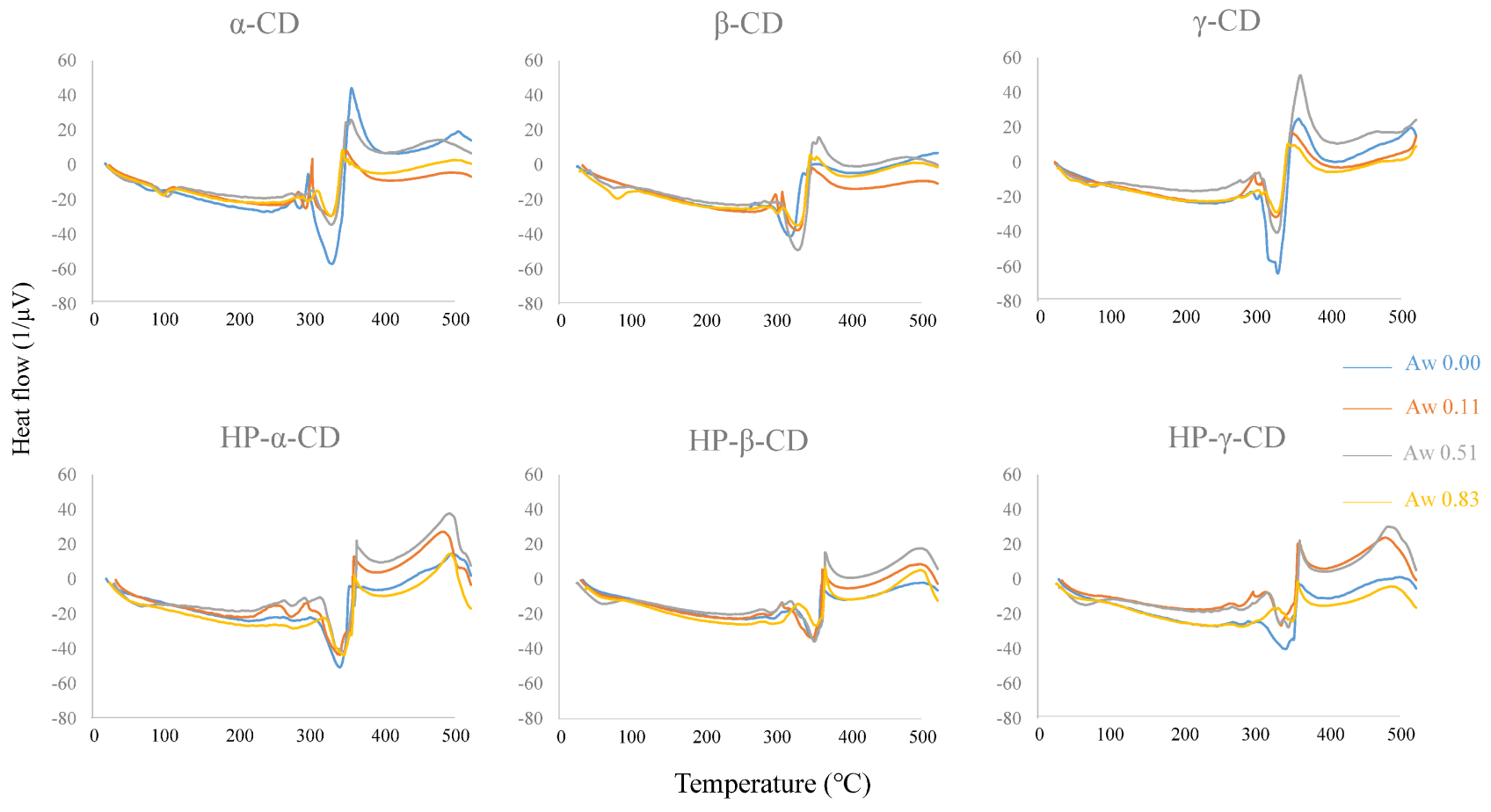

Fig. 6. DTA Curves of Different Type CDs

(Color figure can be accessed in the online version.)
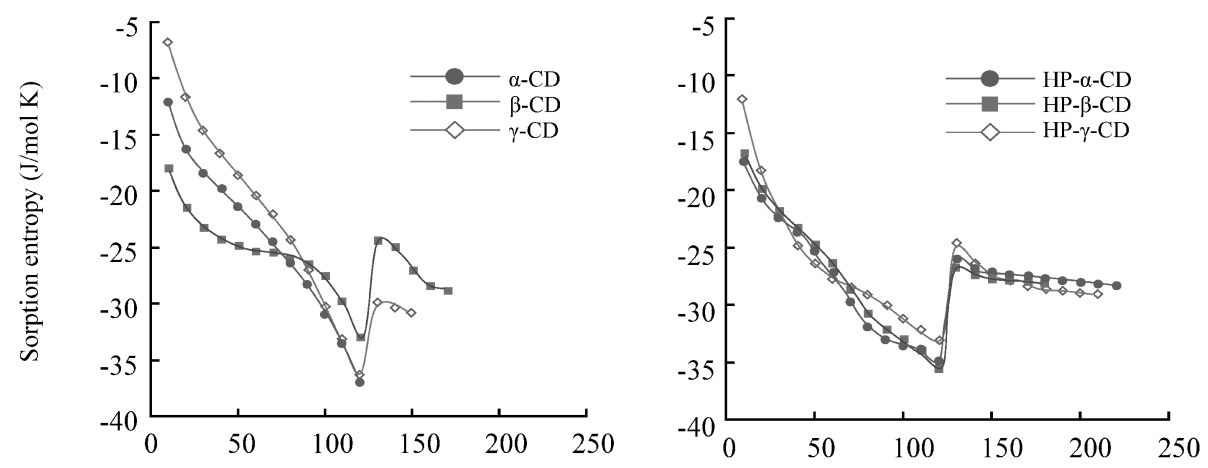

Moisture content $(\mathrm{mg} / \mathrm{g})$

Fig. 7. Changes in Sorption Entropy Using Different Type CDs
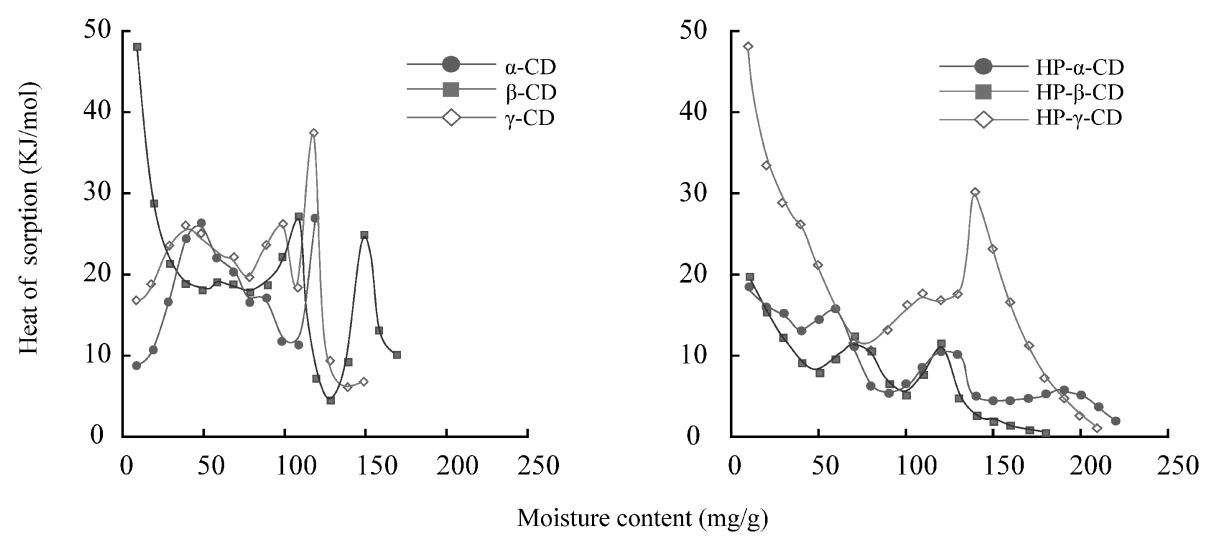

Fig. 8. Changes in Heat of Sorption Using Different Type CDs 
果，すべての $\mathrm{CD}$ において，約 $100^{\circ} \mathrm{C}$ 付近で水分子 の蒸発による重量の減少が観察された。 CD と HP$\mathrm{CD}$ の重量減少を比較すると, HP-CD の方が大き くなった，さらに，その減少量は Aw に依存して増 大することが分かった。これらは Table 2 で示した $\mathrm{R}$ 值からも明らかなように，1 分子の $\mathrm{CD}$ が保有で きる水分子の数が多いためであると考えられる．ま た， $\alpha-\mathrm{CD} ， \beta-\mathrm{CD}$ 及び $\gamma-\mathrm{CD}$ の融点は，それぞれ $278^{\circ} \mathrm{C}, 260^{\circ} \mathrm{C}$ 及び $300^{\circ} \mathrm{C}$ であり，本研究条件下に おいても約 $300^{\circ} \mathrm{C}$ 付近で急激な重量の減少が認めら れた。 HP-CD においても同様の傾向が観察され た。すなわち，CDに含有されている炭素が燃焼時 に酸素と反応して，二酸化炭素と水に変化したため であると考えられる。

次に示差熱分析の結果を Fig. 6 に示す。示差熱 分析では負の值は吸熱を，正の值は発熱を意味す る. 本研究条件下においては, 約 $300^{\circ} \mathrm{C}$ 付近で吸熱 反応が，約 $350^{\circ} \mathrm{C}$ 付近で発熱反応が観察された。先 行研究より，セルロースやマルトースにおいても吸 熱反応に続く発熱反応が報告されており, ${ }^{20)}$ 同様の 傾向を示したと考えられる．先の熱重量分析の結果 (Fig. 5) より, 各種 $\mathrm{CD}$ は約 $300-350^{\circ} \mathrm{C}$ 付近で重 量の顕著な現象が認められた。示差熱分析の結果 (Fig. 6) においても約 $300-350^{\circ} \mathrm{C}$ 付近で急激な熱 変動が観察され，各種 $\mathrm{CD}$ の構造が完全に崩壊した と考えられる。 また， HP- $\alpha-C D ， H P-\beta-C D$ 及び HP- $\gamma$-CD を用いた場合の熱変動においては，CD と比較し若干高温度側にシフトしていた。これらは $\mathrm{CD}$ と比較し，修飾に用いられたヒドロキシプロピ ル基由来の炭素数が増加した結果，HP-CD の分解 に必要な熱エネルギーが増大したためと考えられ る。 また，HP-CD のヒドロキシプロピル基のモル 置換度は 0.6 と同一のために，各 HP-CD 間で顕著 な差は認められなかった。

最後に, 各種 CD と水分子との相互作用を明らか とするために水分子の収着エントロピーの変化を評 価した（Fig. 7)。その結果， CD 及び HP-CD とも に同様の挙動を示した。すなわち，水分子の収着量 が約 $125 \mathrm{mg} / \mathrm{g}$ までの領域ではエントロピーの減少 が確認でき，CD と水分子との相互作用が強く，自 由度が低下していると考えられる，また，水分子の 収着量が約 $125 \mathrm{mg} / \mathrm{g}$ 以上の領域では，一時的な工 ントロピーの増大が認められた。これは， $\mathrm{CD}$ と相
互作用する自由水が増加したためであると考えられ る.さらに, CD 及び HP-CD の水分子の微分収 着熱を評価した（Fig. 8)。微分収着熱は，増減を 繰り返していることが明らかとなり，吸収された水 分子の一部は，吸収後，澎張していることが確認で きた。さらに，微分収着熱は $0-50 \mathrm{KJ} / \mathrm{mol}$ の範囲 内で変動しており, CD 及び HP-CD と水分子との 相互作用には，水素結合 $(2-80 \mathrm{KJ} / \mathrm{mol})$ 及びファ ンデルワールスカ $(0.5-20 \mathrm{KJ} / \mathrm{mol})$ が関与してい ることを確認できた。

先述したように，CD をヒドロキシプロピル基で 修飾した HP- $\beta-C D$ は，医薬品分野において盛んに 研究されている。それと並行して，各動物種を用い た遺伝毒性や発がん性などの毒性評価に関する検討 も実施されている，さらに，ヒト体内における薬物 動態及び代謝機構に関する研究調査も実施されてお り，HP- $\beta$-CD はヒトに対して毒性が非常に低いこ とが明らかとなっている. ${ }^{21)}$

以上のことから，本研究においては $\mathrm{CD}$ と水分子 との相互作用に関する知見を得ることに成功した.

水分子の収着・脱着等温線の結果より, HP-CD と 水分子との相互作用はヒステリシスになることなく 可逆的な反応であることが示唆された，さらに，新 たに $\mathrm{R}$ 值を算出することができ， HP- $\alpha-\mathrm{CD} ， \mathrm{HP}-$ $\beta-\mathrm{CD}$ 及び HP- $\gamma-\mathrm{CD}$ を用いた場合，それぞれ 12.5 分子， 14.0 分子及び 16.7 分子の水分子を収着でき ることを明らかとした。 また，HP-CD による水分 子との相互作用には，吸着が強く関与していること が明らかとなった。水分子の収着エントロピー及び 微分収着熱の結果より，本実験条件下においては， CD 及び HP-CD ともに水分子との相互作用には, 水素結合及びファンデルワールスカが関与している ことを確認できた。

利益相反＼cjkstart開示すべき利益相反はない.

\section{REFERENCES}

1) Terao K., Komiyama M., “Applied Technology of Cyclodextrin," CMC Publishing Co., Ltd., Tokyo, 2013, pp. 3-138.

2) Mifune A., Shima A., Yuki Gosei Kagaku Kyokai Shi, 35, 116-130 (1977).

3) Yoshii H., Nippon Shokuhin Kagaku Kogaku 
Kaishi, 51, 647-655 (2004).

4) Hara K., Hashimoto H., J. Jpn. Soc. Starch Sci., 33, 152-161 (1986).

5) Nakai Y., Yamamoto K., Terada K., Kajiyama A., Sasaki I., Chem. Pharm. Bull., 34, 2178-2182 (1986).

6) Kawano K., Nakai Y., Yakugaku Zasshi, 105, 1071-1077 (1985).

7) Manabe M., Ito T., Kawamura H., Ikushima K., Kagimoto H., Nippon Kagaku Kaishi, 957-961 (1993).

8) Fujiwara T., Nihon Kessho Gakkaishi, 24, 5464 (1982).

9) Ueda H., Proc. Hoshi Univ., 34, 1-12 (1992).

10) Yergey A. L., Blank P. S., Cologna S. M., Backlund P. S., Porter F. D., Darling A. J., PLOS ONE, 12, e0175478 (2017).

11) Variant Pharmaceuticals, Inc., Variant Pharmaceuticals Completes Pre-IND Meeting with FDA on VAR 200 for Focal Segmental Glomerulosclerosis (FSGS), a Rare Kidney Disease: / https: / / www.prnewswire.com / news-releases / variant-pharmaceuticals-com pletes-pre-ind-meeting-with-fda-on-var-200-for- focal-segmental-glomerulosclerosis-fsgs-a-rarekidney-disease-300629892.html $\rangle$, cited 1 May, 2020.

12) Braga S. S., Biomolecules, 9, 801 (2019).

13) Lewis G., J. Res. Natl. Bur. Stand., A Phys. Chem., 81, 89-96 (1977).

14) Boki K., Kawasaki N., Minami K., Tadokoro S., J. Jpn. Soc. Starch Sci., 40, 365-373 (1993).

15) Kuwabara T., J. Ion Exchange, 24, 82-87 (2013).

16) Uekama K., Hirayama F., Arima H., Yakuzaigaku, 67, 66-79 (2007) .

17) Nakai Y., Yamamoto K., Terada K., Sasaki I., Yakugaku Zasshi, 106, 420-424 (1986).

18) Loftsson T., Brewster M. E., J. Pharm. Pharmacol., 63, 1119-1135 (2011).

19) Uekama K., Yakugaku Zasshi, 101, 857-873 (1981).

20) Takeuchi T., Saito K., Polymers, 12, 831-842 (1963).

21) Gould S., Scott R. C., Food Chem. Toxicol., 43, 1451-1459 (2005). 